Bull. Chem. Soc. Ethiop. 2017, 31(3), 465-469.

ISSN 1011-3924

(C) 2017 Chemical Society of Ethiopia and The Authors

Printed in Ethiopia

DOI: http://dx.doi.org/10.4314/bcse.v31i3.10

\title{
ISOLATION OF NON-CYTOTOXIC CROTEPOXIDE FROM THE ROOT BARK OF CROTON MACROSTACHYUS AND THE REASSIGNMENT OF ITS STRUCTURE
}

\author{
Zelalem Yibralign Desta ${ }^{1,2^{*}}$ and Norbert Sewald ${ }^{2}$ \\ ${ }^{1}$ Department of Chemistry, Bahir Dar University, P. O. Box 79, Bahir Dar, Ethiopia; \\ ${ }^{2}$ Departmentof Chemistry, Organic and Bioorganic Chemistry, Bielefeld University, P. O. Box \\ 100131, 33501 Bielefeld, Germany
}

(Received October 25, 2016; Revised December 18, 2017; Accepted December 21, 2017)

\begin{abstract}
Crotepoxide was isolated for the first time from the root bark of Croton macrostachyus along with other known compounds. This compound along with other compounds was investigated for cytotoxicity and found to be not active against the human cervix carcinoma KB-3-1 cells in micromolar ranges. In addition, the ${ }^{13} \mathrm{C} \mathrm{NMR}$ of crotepoxide is reassigned. The structures of the compounds in general were elucidated on the basis of extensive spectroscopic (1D and 2D) studies and literature data.
\end{abstract}

KEY WORDS: Croton macrostachyus, Crotepoxide, Structure revision, Root bark, Cytotoxicity

\section{INTRODUCTION}

The genus Croton is one of the largest genera of flowering plants, with nearly 1300 species of herbs, shrubs, and trees that are ecologically prominent and often important elements of secondary vegetation in the tropics and subtropics of the worldwide [1]. Croton macrostachyus Hochst (Euphorbiaceae) is a medium sized deciduous tree of East Africa, particularly wide spread between 200-2500 $\mathrm{m}$ in mountainous forests and savannah of the tropical regions and ever green bush land areas that receive between $700-2000 \mathrm{~mm}$ rainfalls annually $[2,3]$. It is native to Ethiopia, Eritrea, Kenya, Tanzania, Uganda, Cameroon and Nigeria [2]. Traditionally the plant is used widely for the treatment of malaria [4], diarrhea, diabetes [2], venereal diseases and haemorrhoids [5]. We herein report the isolation and structure revision of crotepoxide 3 along with other known compounds from the root bark of C. macrostachyus.

\section{RESULTS AND DISCUSSION}

Compound 3 was obtained as a colourless paste. The compound has the molecular formula $\mathrm{C}_{18} \mathrm{H}_{18} \mathrm{O}_{8}$ which implied 10 degrees of unsaturation. The ${ }^{13} \mathrm{C}$ NMR spectrum gave a total of eighteen carbon signals and together with the DEPT and HMQC spectra further confirmed that thirteen of these were protonated carbon signals while the other five were quaternary carbon signals. The compound was isolated and reported for the first time in 1968 from the fruits of the C. macrostachyus which was collected from Ethiopia [7] but the authors did not report the ${ }^{13} \mathrm{C}$ NMR. However, the authors reported only the chemical shifts of the protons and they reported five aromatic protons as a multiplet [7] but during our investigation the ${ }^{1} \mathrm{H}$ NMR spectra of the compound showed these five aromatic protons separately at different chemical shifts (Table 1). Furthermore, the compound was also isolated and reported in 2004 from the fruits of the $C$. macrostachyus [3] but the authors reported the compound along with one novel compound without reporting the NMR data of crotepoxide. In another investigation, Gelaw et al. reported this compound from the berries of C. macrostachyus in 2012 [8] with wrong assignment of the

*Corresponding author. E-mail: yibrazelalem@yahoo.com

This work is licensed under the Creative Commons Attribution 4.0 International License 
NMR data only by referring the 2004 report [3] which did not contain the NMR data of the compound. The structure of the compound 3 during our investigation was confirmed from extensive studies of spectroscopic data (1D and 2D experiments) together with literature data. Its ${ }^{1} \mathrm{H}$ and ${ }^{13} \mathrm{CNMR}$ data found to be similar to those reported by Gelaw et al. [8]. However, the ${ }^{13} \mathrm{C}$ assignment of the aromatic ring and the acetyl groups by Gelaw et al. is different from our assignment. In the HMQC spectrum, the aromatic region of the proton NMR spectrum showed that the proton signal at $\delta_{\mathrm{H}} 8.06 \mathrm{ppm}\left(\mathrm{H}-2^{\prime}, 6^{\prime}\right)$ correlated with carbon signal at $\delta_{\mathrm{C}} 129.8 \mathrm{ppm}$, the proton signal at $\delta_{\mathrm{H}} 7.62 \mathrm{ppm}\left(\mathrm{H}-4^{\prime}\right)$ correlated with carbon signal at $\delta_{\mathrm{C}} 133.6$ and the proton signal at $\delta_{\mathrm{H}} 7.48 \mathrm{ppm}\left(\mathrm{H}^{\prime} 3^{\prime}, 5^{\prime}\right)$ correlated with carbon signal at $\delta_{\mathrm{C}} 128.6$ which was assigned to (H-2', 6') by Gelaw et al. [8]. The assignment of the aromatic protons was further supported by COSY correlations. In the COSY spectrum, the proton at $\delta_{\mathrm{H}} 8.06\left(\mathrm{H}-2^{\prime}\right)$ correlated with a proton at $\delta_{\mathrm{H}} 7.48\left(\mathrm{H}-3^{\prime}\right)$ and the proton signal at $\delta_{\mathrm{H}} 7.48\left(\mathrm{H}-3^{\prime}\right)$ correlated with both protons at $\delta_{\mathrm{H}} 8.06$ $\left(\mathrm{H}-2^{\prime}\right)$ and $7.62\left(\mathrm{H}-4^{\prime}\right)$. Apart from this, the assignment for the acetate groups by Gelaw et al. was wrong. This was confirmed from $\mathrm{HMBC}$ spectrum indicating that the proton at $\delta_{\mathrm{H}} 2.14 \mathrm{ppm}$ correlated with carbons at $\delta_{\mathrm{C}} 170.1(\mathrm{C}-8)$ and $69.4(\mathrm{C}-2)$ and the proton at $\delta_{\mathrm{H}} 2.03$ correlated with carbons at $\delta_{\mathrm{C}} 169.7(\mathrm{C}-10)$ and $70.4(\mathrm{C}-3)$ which were interchangeably assigned in Gelaw et al. report. Based on this analysis, we assigned the correct NMR data for compound $\mathbf{3}$ as shown in Table 1. Other known compounds identified from the root bark of Croton macrostachyus along with crotepoxide 3 are lupeol $\mathbf{1}[5,6]$, derivative of betulinic acid 2 [5], $\beta$-sitosterolpalmitate 4 [5] and betulin $5[5,6]$.

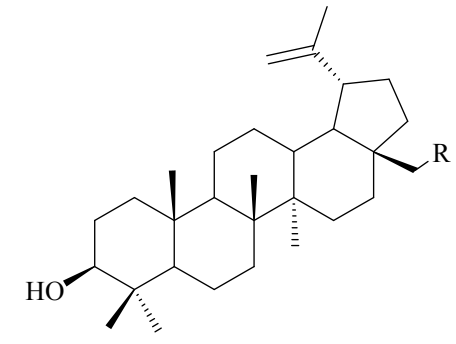

1. $\mathbf{R}=\mathbf{H}$, Lupeol 5. $\mathbf{R}=\mathbf{O H}$, Betulin

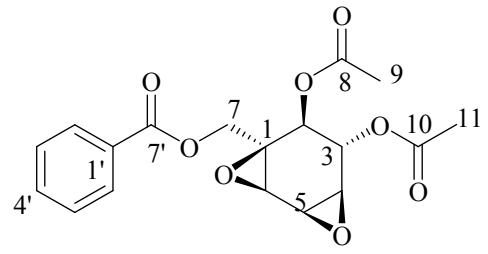

3

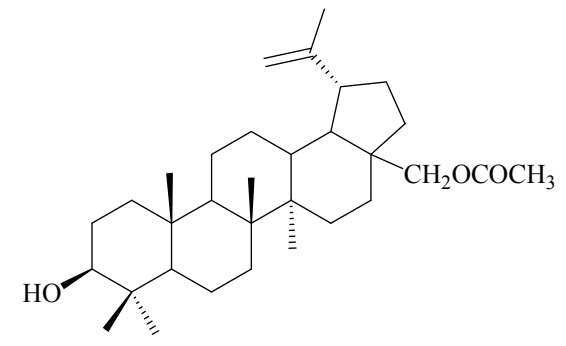

2. 28-O-acetylbetulin

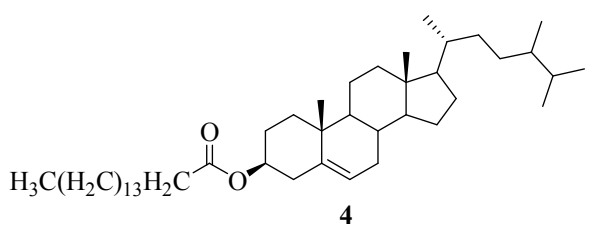

Figure 1. Chemical structures of some compounds isolated from C. macrostachyus.

\section{Cytotoxicity Test}

Three pure compounds were evaluated for cytotoxicity. The method used for this cytotoxicity test was the cell-based resazurin cytotoxicity assay with fluorescence read-out. Human cervix carcinoma KB-3-1 cells were used and the reduction of the resazurin to resorufin was used as read out. Of the three pure isolates, compounds 1, 3 and 5 were found to be inactive against the human cervix carcinoma KB-3-1 cellsin the micromolar range (Table 2). 
Table 1. The ${ }^{1} \mathrm{H}$ and ${ }^{13} \mathrm{C}$ NMR data of crotepoxide compared with literature data.

\begin{tabular}{|l|l|l|l|l|}
\hline No. & \multicolumn{2}{|c|}{ Observed data } & \multicolumn{3}{c|}{ Reported data [8] } \\
\hline & ${ }^{1} \mathrm{H}$ NMR & ${ }^{13} \mathrm{C}$ NMR & ${ }^{1} \mathrm{H}$ NMR & ${ }^{13} \mathrm{C}$ NMR \\
\hline 1 & - & 59.39 & - & 59.42 \\
\hline 2 & $5.71, d(5.0)$ & 69.43 & 5.71 & 69.44 \\
\hline 3 & $5.00, d d(10.0,5.0)$ & 70.37 & 5.00 & 70.37 \\
\hline 4 & $3.11, d(5.0)$ & 52.61 & 3.11 & 52.62 \\
\hline 5 & $3.47, d(5.0)$ & 48.07 & 3.46 & 48.07 \\
\hline 6 & $3.68, d(5.0)$ & 53.82 & 3.67 & 53.8 \\
\hline 7 & $4.58, d(15.0)$ & 62.46 & 4.59 & 62.44 \\
\hline & $4.26, d(10.0)$ & 62.46 & 4.26 & 62.44 \\
\hline 8 & - & 170.05 & - & 169.75 \\
\hline 9 & $2.14, s$ & 20.68 & 2.03 & 20.67 \\
\hline 10 & - & 169.74 & - & 170.05 \\
\hline 11 & $2.05, s$ & 20.64 & 2.13 & 20.67 \\
\hline $1^{\prime}$ & - & 129.11 & - & 129.12 \\
\hline $2^{\prime}$ & $8.06, d d(10.0,5.0)$ & 129.80 & 8.04 & 128.57 \\
\hline $3^{\prime}$ & $7.48, d d(10.0,5.0)$ & 128.56 & 7.49 & 129.79 \\
\hline $4^{\prime}$ & $7.62, d d(10.0,5.0)$ & 133.55 & 7.62 & 133.55 \\
\hline $5^{\prime}$ & $7.48, d d(10.0,5.0)$ & 128.56 & 7.49 & 129.79 \\
\hline $6^{\prime}$ & $8.06, d d(10.0,5.0)$ & 129.80 & 8.04 & 128.57 \\
\hline $7^{\prime}$ & - & 165.78 & - & 165.77 \\
\hline
\end{tabular}

Table 2. Cytotoxicity data for some isolated pure compounds.

\begin{tabular}{|c|c|c|}
\hline Compound & $\mathrm{IC}_{50}(\mu \mathrm{M})$ & Activity \\
\hline $\mathbf{1}$ & $0.005-48.8$ & na \\
\hline $\mathbf{3}$ & $0.005-48.8$ & na \\
\hline $\mathbf{5}$ & $0.005-48.8$ & na \\
\hline
\end{tabular}

Key: a: active; na: not active.

\section{EXPERIMENTAL}

\section{General}

${ }^{1} \mathrm{H}$ NMR, ${ }^{13} \mathrm{C}$ NMR, DEPT, COSY, HMQC, and HMBC were recorded using Bruker Avance DRX $500 \mathrm{MHz}$ spectrometers using standard pulse sequences and referenced to residual solvent signals. Column chromatography was carried out on silica gel 60 (0.040-0.063 mm, Merck). Preparative TLC $(0.5 \mathrm{~mm}$ thick) and analytical TLC were performed with precoated Merck silica gel 60 PF254 plates. Visualization of chromatograms was made under UV light (254 and $366 \mathrm{~nm}$ ) and further by potassium permanganate solution spray, followed by heating.

\section{Plant material}

The root and stem barks of the Croton macrostachyus were collected from Amhara Regional State, Awi Administrative Zone (Gojjam), Ankesha Gogusa woreda, particularly from Azena (Mochegere) in January 2015.

\section{Extraction and isolation}

The air-dried $600 \mathrm{~g}$ of the root bark of $C$. macrostachyus was ground and extracted by soaking successively in petroleum ether, ethyl acetate and methanol: dichloromethane (1:1) each for 24 hours (three times with each solvent). Removal of the solvent under reduced pressure using a 
Buchi flash evaporator to afford a white powder extract of $11.0 \mathrm{~g}$ for petroleum ether, $7.0 \mathrm{~g}$ black gummy extract for EtOAc and $17.0 \mathrm{~g}$ black gummy extract for methanol: dichloromethane $(1: 1)$.

$11.0 \mathrm{~g}$ of the petroleum ether extract was adsorbed onto $11.0 \mathrm{~g}$ of silica gel and applied on a column which was packed with $100 \%$ of petroleum ether and eluted with $100 \%$ petroleum ether containing increasing amounts of EtOAc (up to $100 \%$ ) to yield a total of 17 fractions each 100 $\mathrm{mL}$. Among these 17 fractions, fractions which were eluted using the solvent system petroleum ether/EtOAc (9:1), i.e. fractions 3-6 were pure and similar and afforded lupeol 1 (2.7 g). In addition to this, fractions 9-10 which were eluted with the solvent system petroleum ether/EtOAc (7:3) were pure and identified as derivative of betulinic acid 2 (339 mg). Fractions 11 and 12 were combined together and applied on preparative TLC and eluted with a solvent system petroleum ether/EtOAc (4:1) (2 developments) and afforded crotepoxide 3 (30 mg) and $3.8 \mathrm{mg} \beta$-sitosterolpalmitate 4 . Based on TLC analysis, other components were long chain fatty acids and further work was not done.

$17.0 \mathrm{~g}$ of the methanol/dichloromethane (1:1) extract was adsorbed onto $17.0 \mathrm{~g}$ of silica gel and applied onto a column which was packed with $100 \%$ of petroleum ether and eluted with $100 \%$ petroleum ether containing increasing amounts of EtOAc (up to $100 \%$ ) to yield a total of 16 fractions each $100 \mathrm{~mL}$. Of 16 fractions, fraction 3 was pure and afforded betulin $\mathbf{5}(100 \mathrm{mg})$. Of 16 fractions, fraction 6 was applied on preparative TLC and eluted with the solvent system petroleum ether/EtOAc (4:1) (2 developments) and afforded two compounds, i.e. crotepoxide 3 $(16.8 \mathrm{mg})$ and another compound which is derivative of long chain fatty acid and its structure is not yet identified. In addition to these, from this extract many compounds were isolated but their structure is not yet identified because of the attachment of long chain fatty acids to the parent compounds.

In addition to the above investigations on the root bark of Croton macrostachyus, we have also investigated some of the extracts of the stem bark of the plant. Lupeol $\mathbf{1}$ and betulin $\mathbf{5}$ were successfully isolated from the petroleum ether and ethyl acetate extract of the stem bark of the plant.

\section{Cytotoxicity test}

Cytotoxic activity of the isolated compounds was done as described [9]. Briefly the KB-3-1 cells were cultivated as a monolayer in a DMEM (Dulbecco's Modified Eagel Medium) with glucose $(4.5 \mathrm{~g} / \mathrm{L})$, L-glutamine, sodium pyruvate and phenol red, supplemented with $10 \%$ (KB3-1) foetal bovine serum (FBS). The cells were maintained at $37{ }^{\circ} \mathrm{C}$ and $5.3 \% \mathrm{CO}_{2}$ humidified air. On the day before the test, the cells ( $70 \%$ confluence) were detached with trypsinethylenediaminetetraacetic acid (EDTA) solution $(0.05 \% ; 0.02 \%$ in DPBS [Dulbecco's Phosphate Buffered Saline]) and placed in sterile 96-well plates in a density of 1000 cells in 100 $\mu \mathrm{L}$ medium per well. The dilution series of the compounds were prepared from stock solutions in DMSO of concentrations of 100,50 or $25 \mathrm{mM}$. The stock solutions were diluted with culture medium (10\% FBS [KB-3-1]) down to $\mathrm{pM}$ range. The dilution prepared from stock solution was added to the wells. Each concentration was tested in six replicates. Dilution series were prepared by pipetting liquid from well to well. The control contained the same concentration of DMSO as the first dilution. After incubation for $72 \mathrm{~h}$ at $37{ }^{\circ} \mathrm{C}$ and $5.3 \% \mathrm{CO}_{2}$ humidified air, $30 \mu \mathrm{L}$ of an aqueous resazurin solution $(175 \mu \mathrm{M})$ was added to each well. The cells were incubated under the same conditions for 5 hours. Subsequently, the fluorescence was measured. The excitation was effected at a wavelength of $530 \mathrm{~nm}$, whereas the emission was recorded at a wavelength of $588 \mathrm{~nm}$. The $\mathrm{IC}_{50}$ values were calculated as a sigmoidal dose response curve using Graphpad Prism 4.03. The $\mathrm{IC}_{50}$ values equal the drug concentration, at which vitality is $50 \%$. 


\section{ACKNOWLEDGEMENTS}

We are very grateful for the financial support from Deutscher Akademischer Austausch Dienst (DAAD, German Academic Exchange Service). We also thank C. Michalek for performing bioactivity tests.

\section{REFERENCES}

1. Radulovic, N.; Mananjarasoa, E.; Harinantenaina, L.; Yoshinori, A. Essential composition of four Croton from Madagascar and their chemotaxonomy. Biochem. System. Ecol. 2006, 34, 648-653.

2. Kapingu, M.C.; Guillaume, D.; Mbwambo, Z.H.; Moshi, M.J.; Uliso, F.C.; Mahunnah, R.L.A. Diterpenoids from the roots of Croton macrostachys. Phytochemistry 2000, 54, 767 770.

3. Tane, P.; Tatsimo, S.; Connolly, J.D. Crotomacrine, a new clerodanediterpenefrom the fruits of Croton macrostachyus. Tetrahedron Lett. 2004, 45, 6997-6998.

4. Bantie, L.; Assefa, S.; Teklehaimanot, T.; Engidawork, E. In vivo antimalarial activity of the crude leaf extract and solvent fractions of Croton macrostachyus Hocsht. (Euphorbiaceae) against Plasmodium bergheiiin mice. BMC Complement. Altern. Med. 2014, 14, 79-88.

5. Tala. M.F.; Tan, N.-U.; Ndontsa, B.L.; Tane, P. Triterpenoids and phenolic compounds from Croton macrostachyus. Biochem. System. Ecol. 2013, 51, 138-141.

6. Tene, M.; Ndontsa, B.L.; Tane, P.; Tamokou, J. De. D.; Kuite, J.-R. Antimicrobial diterpenoids and triterpenoids from the stem bark of Croton macrostachys. Int. J. Biol. Chem. Sci. 2009, 3, 538-544.

7. Kupchan, S.M.; Hemingway, R.J.; Coggon, P.; McPhail, A.T.; Sim, G.A. Crotepoxide, a novel cyclohexane diepoxidetumor inhibitor from Croton macrostachys. J. Am. Chem. Soc. 1968, 90, 2982-2983.

8. Gelaw, H.; Adane, L.; Tariku, Y.; Hailu, A. Isolation of crotepoxide from berries of Croton macrostachyus and evaluation of its anti-leishmanial activity. J. Pharmacogn. Phytochem. 2012, 1, 15-23.

9. Sammet, B.; Bogner, T.; Nahrwold, M.; Weiss, C.; Sewald, N. Approaches for the synthesis of functionalized cryptophycins. J. Org. Chem. 2010, 75, 6953-6960. 